Hamline University

DigitalCommons@Hamline

\title{
The Impact of the 1990's Economic Boom on Less Educated Workers in Rural America
}

\author{
Elizabeth E. Davis \\ University of Minnesota - Twin Cities \\ Stacie Bosley \\ Hamline University, sbosley@hamline.edu
}

Follow this and additional works at: https://digitalcommons.hamline.edu/hsb_faculty

Part of the Labor Economics Commons

\section{Recommended Citation \\ Davis, Elizabeth E. and Bosley, Stacie, "The Impact of the 1990's Economic Boom on Less Educated Workers in Rural America" (2007). School of Business All Faculty Scholarship. 1. \\ https://digitalcommons.hamline.edu/hsb_faculty/1}

This is the author's working paper copy before peer reviewed edits. The final, definitive version of this document can be found online at Community Development published by Taylor \& Francis. Copyright restrictions apply. doi: $10.1080 / 15575330709490185$

This Article is brought to you for free and open access by the School of Business at DigitalCommons@Hamline. It has been accepted for inclusion in School of Business All Faculty Scholarship by an authorized administrator of DigitalCommons@Hamline. For more information, please contact digitalcommons@hamline.edu. 


\title{
The Impact of the 1990s Economic Boom on Less-Educated Workers in Rural America:
}

\section{Did the Rising Tide Lift All Boats?}

\author{
by \\ Elizabeth E. Davis and Stacie A. Bosley \\ Department of Applied Economics \\ University of Minnesota
}

\begin{abstract}
Selected Paper To Be Presented at the 2002 Annual Meeting of the American Agricultural Economics Association (AAEA), Long Beach, California

DRAFT

May 15, 2002

Do Not Cite Without Authors' Permission
\end{abstract}

Copyright 2002 by Elizabeth E. Davis and Stacie A. Bosley. All rights reserved. Readers may make verbatim copies of this document for non-commercial purposes only by any means, provided that this copyright notice appears on all such copies.

Email: edavis@apec.umn.edu 


\begin{abstract}
We use national longitudinal survey data (NLSY79) to investigate the impact of local labor market conditions on the employment and earnings of rural non-college-educated workers. Results suggest that local economic conditions in the late 1990s did have a positive impact on wages, and the effect is larger for workers with no more than a high school degree compared to their college-educated counterparts. We find little evidence of a difference between rural and urban impacts, suggesting that the 1990s boom helped both rural and urban less-educated workers. These results suggest that an expanding economy continues to be a powerful anti-poverty force.
\end{abstract}




\section{Introduction}

The expression "a rising tide lifts all boats" sums up the belief that economic growth raises income for everyone. Indeed, in the 1960s economic growth in the United States was a powerful force for the reduction of poverty. In more recent decades, economists have questioned whether the growing economy has continued to have the same impact on poverty. In particular, in the 1980s researchers found that the relationship between growth and poverty reduction was significantly weakened.

Even though the longest economic expansion in the U.S. has now officially ended with a recession beginning in March 2001, the period of sustained growth in the 1990s provides an unprecedented opportunity to re-examine the impact of local economic conditions on disadvantaged workers. Studies to-date suggest that in metropolitan areas of the U.S., the 1990s boom did help disadvantaged workers by increasing wages and decreasing unemployment. However, few studies have examined the impact of the 1990s expansion on worker outcomes in rural areas.

This research builds upon two main strands of the literature. First, we draw on research that takes advantage of differences in local labor market conditions to examine the impact of overall economic conditions on individual outcomes, particularly for lowincome or economically disadvantaged groups. As discussed below, most studies have found that, in metropolitan areas, local economic conditions have a larger impact on less skilled or more disadvantaged workers than on more skilled or older workers. In addition, our research draws upon the literature related to the "wage curve" of Blanchflower and Oswald, who find a negative relation between wages and unemployment rates across countries, regions, and time that is remarkably consistent. 
In this paper we find that local economic conditions in the late 1990s did have a positive impact on wages, and that the impact is larger for workers with no more than a high school degree, compared to their more highly educated counterparts. We find little evidence of a difference between rural and urban impacts, suggesting that the 1990s boom helped both rural and urban less-educated workers. These results suggest that an expanding economy continues to be a powerful anti-poverty force. Given the end of the 1990s expansion in recent months, however, policymakers may once again be concerned about the wages and economic outlook for non-college educated workers.

\section{Conceptual Framework and Relevant Literature}

Local labor market conditions may impact a worker's earnings and/or labor supply decision by affecting average wages or the likelihood of finding a job. ${ }^{1}$ For example, in a job search model, better economic conditions in a labor market are likely to impact the distribution of wage offers. For an individual job seeker, higher employment growth in an area is likely to lead to an increase in the frequency of job offers, raising the probability of employment. It may also improve wage offers, increasing earnings, all else equal (Hoynes, 2000). In a job-queuing model, better local economic conditions may increase wages and employment of disadvantaged workers by both reducing unemployment and increasing upward mobility into higher wage jobs (Bartik 1996).

There are a growing number of studies that take advantage of differences in local labor market conditions to examine the impact of overall conditions on individual outcomes, particularly for low-income or economically disadvantaged groups. Hoynes

\footnotetext{
${ }^{1}$ Labor supply is frequently modeled as a joint household decision in the case of married adults. Unfortunately our data do not allow us to model the labor supply decisions of husbands and wives jointly. Tokle and Huffman provide an example of estimation of a joint labor supply model.
} 
(1988) examines the impact of business cycles for different subgroups based on race, gender and education by relying on variations in economic conditions across MSAs (metropolitan statistical areas). She finds that wages of less skilled workers are affected more by economic conditions than those of more skilled workers. Freeman and Rodgers focus on the 1990s expansion and find that the impact of favorable local economic conditions has been greatest for younger men (under age 25) and for African American men. Bartik (1996) and Bound and Holzer also find that employment growth leads to wage increases for younger, less experienced workers in urban areas.

In addition, our research is related to the literature on the "wage curve." Blanchflower and Oswald find a negative empirical relation between wages and unemployment rates across countries, regions, and time that is remarkably consistent. This inverse relationship between wages and unemployment contrasts with a HarrisTodaro model of regional economies, in which areas with higher unemployment rates have higher wages (a compensating differential, in effect). Blanchflower and Oswald suggest that while this model may hold in the long run, at a point in time the crosssectional relationship between wages and unemployment is negative. In support of their empirical findings, they present a number of labor contracting and wage efficiency models that could produce such a relationship.

Two recent papers address the "rising tide" question more directly using aggregate data. Hines, Hoynes and Krueger use aggregate measures of labor market outcomes at the MSA-level to estimate the impact of changes in unemployment over the business cycle. They find that employment, wages and hours worked for low-skilled workers increase during expansions and decrease during recessions, though the impact on 
wages is fairly small. Freeman (2001) examines the effect on state poverty rates of changes in the unemployment rate and average earnings. He concludes that expansions with low unemployment rates (4-5\%) and rising real wages will reduce poverty, though he notes that many people will remain poor due to barriers to labor force participation.

\section{Data and Methods}

In this study our primary source of data is the 1979 National Longitudinal Survey of Youth (NLSY79). The Bureau of Labor Statistics began surveying a group of about 12,000 youth aged 14 to 22 in 1979 and has interviewed them annually since then (biannually since 1994). While the sample has undergone some revisions, the retention rate in 1998 for those who remain eligible was $84 \%$. The NLSY79 includes extensive data on demographic and family characteristics, and work history and earnings. Under special agreement with the Bureau of Labor Statistics, we obtained the NLSY79 geocode data, which provides more detailed information on the location of respondents (e.g., county of residence). ${ }^{2}$ This information allows us to compare findings using different definitions of "rural."

One of our main objectives in this study is to investigate the effect of using different geographical units and definitions of "rural" compared with other studies. Recent studies use various definitions of local labor markets. Several use metropolitan statistical areas (MSAs) (Bound and Holzer; Hoynes, 1999; Bartik, 1991, 1996; Freeman and Rogers; Cain and Finnie), while others use state-level data (Tokle and Huffman; Freeman). In analyses of local labor market conditions and welfare spells, Hoynes (2000)

\footnotetext{
${ }^{2}$ Use of the confidential geocode data is subject to special agreement with the Bureau of Labor Statistics. Researchers wishing to use these data must apply to BLS directly.
} 
uses counties, and Fitzgerald uses both counties and Labor Market Areas as defined by the USDA Economic Research Service to define local labor markets.

In this study, we use commuting zones as defined by Tolbert and Sizer as the relevant labor market for each individual. The Tolbert and Sizer commuting zones are counties grouped together based on actual commuting patterns found in Census data. The commuting zones typically include several counties and can cross state boundaries. As shown in table 1, Tolbert and Sizer classify commuting zones based on the size of the largest population center. For this study, we define "rural" labor markets as nonmetropolitan commuting zones. ${ }^{3}$

The commuting zone approach provides a more realistic approximation of the labor market opportunities faced by an individual. States are generally too large and counties too small to reflect a local labor market. Also, in order to examine the effect in rural areas, areas outside of MSA's must be included.

One of the advantages of using the NLSY79 data is that it is a panel data set, tracking the same individuals over time, so we can control for unobserved individual effects. In addition, by using the geocode data, we can more accurately identify the type of labor market where the individual resides. However, there are some disadvantages to using the NLSY79 data for this type of study. The first drawback is the limited age range of respondents. By 1998, the respondents were between 33 and 41 years of age. Thus while the respondents are in their prime labor market years, we are unable to examine the impacts of local economic conditions on younger or older workers. Freeman and Rodgers, for example, find significant differences in the impacts on younger (under age

\footnotetext{
${ }^{3}$ We also used the NLSY definitions of smsa (e.g., living in a metropolitan county) and rural (living in a county that is $0-49 \%$ urbanized) to compare results. While the samples are not identical, the results are qualitatively similar regardless which definition is used.
} 
25) workers and others. A second drawback of the NLSY79 data for this study is that the number of respondents in the key category of interest, non-college educated workers in rural areas, is fairly small (less than 300).

\section{Local Economic Conditions and Local Labor Markets}

A number of different variables have been used to measure labor market conditions: unemployment rates (Freeman and Rodgers; Fitzgerald); predicted employment growth, which is a proxy for labor demand calculated by weighting national sectoral growth rates by local industry sectoral shares (Bound and Holzer); changes in the “wage premium” implied by regional industry mix (Bartik, 1996); and employment

growth (Bartik, 1991, 1996). We use two alternative measures: total employment growth (percent change in total employment in the county) and area unemployment rate.

Figure 1 shows how average annual job growth has varied across the different types of commuting zones between 1993 and 1998. While total employment tended to increase faster in the metropolitan commuting zones in 1996 and 1998 than in the nonmetropolitan areas, the same is not true earlier. In 1993 and 1994, jobs grew faster in two of the three non-metropolitan categories compared with most of the metropolitan ones. Only in the smallest, most rural commuting zones has job growth consistently been lower than elsewhere.

Figure 2 shows the trends in unemployment rates across commuting zones. Unemployment rates were slightly higher in 1993 and 1994 in the non-metropolitan commuting zones than the metro areas. Unemployment rates trended downwards in the mid to late 1990s in all categories and were similar by 1998 across commuting zone 
types. Within commuting zone types, unemployment rates and employment growth rates varied considerably, though on average all improved during the 1990s expansion.

\section{Model and Estimation}

In order to estimate the impact of local labor market conditions on wage and employment outcomes, we estimate a reduced form model of the following basic form:

$$
\mathrm{Y}_{\mathrm{i}}=\beta^{\prime} \mathrm{X}_{\mathrm{i}}+\gamma^{\prime} \mathrm{LM}_{\mathrm{i}}+\mathrm{e}_{\mathrm{i}}
$$

where $Y_{i}=$ the employment outcome for individual $i ; X_{i}=$ a vector of human capital and demographic variables, $\mathrm{LM}_{\mathrm{i}}=$ measures of local labor market conditions in the county, and $\mathrm{e}_{\mathrm{i}}$ is a random error term. This approach is similar to that used by Bartik (1996), Bound and Holzer, and Freeman and Rodgers. We estimate models for three outcome measures: hourly wage, weekly wage, and the probability of employment. ${ }^{4}$ Each of the wage equations is estimated using the Heckman sample selection correction technique. ${ }^{5}$ All standard errors are estimated using the Huber-White robust method.

Control variables in each model are fairly standard for wage employment equations. ${ }^{6}$ Means and standard deviations for all variables are shown in table 2. Sociodemographic variables included are the individual's age, gender, highest grade completed, marital status, race/ethnicity, total work experience (hours) and experience

\footnotetext{
${ }^{4}$ We also estimated a multinomial logit model where the outcomes are employed, unemployed and out of the labor force. The results are similar to the model presented here in that factors that increase the probability of employment decrease the probability of unemployment.

${ }^{5}$ We face the common difficulties in specification of the selection equation. We include age, education, race, gender, marital status, number of children, education of parent, work experience and experience squared, south, and the local economic condition variable in the selection equation. Full results are shown in the appendix.

${ }^{6} \mathrm{We}$ ran separate estimations for men and women and found that the coefficients on the local labor economic condition variables were quite similar for the wage equations, suggesting that pooling the data does not impact the key results. Not surprisingly, perhaps, the estimated equations on employment were quite different for men and women. In future work we will estimate these models separately for men and women.
} 
squared, length of time in current job (tenure) and tenure squared. In addition, dummy variables are included for union status, major industry and occupational categories, south census region, and rural (defined based on commuting zone category).

Local labor market conditions are measured in two ways: local unemployment rate and change in local employment. We test whether the impact of local labor market conditions is different in rural versus urban areas by including an interaction term between the rural dummy and either the unemployment rate or the employment growth rate.

\section{Results}

In this section we first examine the impact of local economic conditions on less educated versus more educated workers, and compare these results to other studies. For the purposes of this study we define "less educated" to include those workers with no more than a high school degree. We then examine the impact in rural versus urban areas to answer the question whether the "rising tide" is indeed helping less educated workers in rural areas. We estimate the models two ways, first using cross-sectional data from 1998 and secondly as a panel data set from 1993-1998 with a fixed effects model. The key results are summarized in tables 3 and $4 .^{7}$

Looking first at the cross-sectional results, it is clear that better local economic conditions in 1998 improved wage outcomes for workers with a high school education or less. For these non-college educated workers, a one percent reduction in the unemployment rate is associated with about a 0.1 percent increase in hourly or weekly wages (both unemployment rate and wage variables are in natural log form) (see table

\footnotetext{
${ }^{7}$ Complete results for the cross-sectional models are shown in the appendix, and the fixed effects results are available upon request from the authors.
} 
3A). This estimate is very similar to the standard "wage curve" (Blanchflower and Oswald). Employment growth also exerts a significant impact on wages, raising wages by 2-3 percent for less educated workers (see table 4A). The impact of local economic conditions is weaker for workers with more than a high school education. While the estimated effects on hourly and weekly wages are significant for employment growth, they are somewhat smaller than for less educated workers. The impact of unemployment rate changes is not statistically significant at the 5 percent level for workers with more than a high school degree.

Using the 1998 data, we find that local economic conditions did not have a statistically significant impact on the likelihood of being employed for either group of workers. The estimated coefficients for the unemployment rate is negative (although not significant). Somewhat surprisingly, the estimated coefficients for employment growth are also negative (though not significant).

One of the concerns with cross-sectional estimates of wages is that unobserved characteristics of an individual may bias the results. Therefore we next used the 1993-98 NLSY79 data to estimate a fixed effects model. ${ }^{8}$ Again we find that the local unemployment rate has a significant inverse relationship with hourly and weekly wages for workers with less than a high school education (see table 3B). The estimated coefficient is about half the size of the cross-sectional estimate. Unlike the 1998 crosssection result, the estimated impact of unemployment rate on the probability of employment is statistically significant using the 1993-98 panel. The estimated impacts of

\footnotetext{
${ }^{8}$ We also estimated a random effects model but found that the Hausman test rejected the random effects assumption.
} 
unemployment rate on wages or employment for workers with more than a high school education are not statistically significant in the fixed effects model.

The fixed effects model results using employment growth as the measure of local economic conditions differ considerably from the cross sectional results. In the fixed effects model, the estimated coefficients on employment growth are not significant for either education group, for either weekly or hourly wages (see table 4B). Employment growth does have a significant positive effect on the likelihood of employment for less educated workers, however.

We used two methods to test whether the impact of local labor market conditions differed in rural versus urban areas: we estimated separate models for rural and urban residents, and we estimated models using the pooled urban and rural data including an interaction term between rural residence and the local economic variable. In both cases, the results were similar. We found no statistically significant differences between rural and urban areas in terms of the impact of either unemployment rate or employment growth on wages or employment status. Finding no effect may be due to small sample sizes, or may in fact indicate that the labor market impacts do not differ on average in rural areas.

\section{Conclusions}

The sustained economic expansion of the 1990s in the United States appears to have helped "to lift all boats," by improving the wages and employment of non-college educated workers. Better local labor market conditions have a stronger impact on outcomes for less educated workers than for those with more than a high school 
education. Using the NLSY79 data, this study confirms findings from studies using alternative data sets about the impacts of local labor market conditions. In addition, unlike other studies, we investigate whether this impact holds true in rural labor markets as well as metropolitan areas. We find that the evidence suggests that, in general, the impact of local labor market conditions on weekly wages is similar for rural and urban workers. The impact on employment status is less clear and suggests the need for further work with better data for rural areas. In addition, improved labor market conditions will primarily help those who are able to participate in the labor market. Poor families facing barriers to labor force participation or unable to work full-time year round struggle despite a growing economy. 


\section{References}

Bartik, Timothy J. 1991. Who Benefits from State and Local Economic Development Policies? Kalamazoo MI: W.E. Upjohn Institute for Employment Research.

Bartik, Timothy J. 1996. "The Distributional Effects of Local Labor Demand and Industrial Mix: Estimates Using Individual Panel Data." Journal of Urban Economics 40, pp. 150-178.

Blank, Rebecca M. 1997a. It Takes a Nation: A New Agenda for Fighting Poverty. Princeton NJ: Princeton University Press.

Blank, Rebecca. 1997b. "Why Has Economic Growth Been Such an Ineffective Tool against Poverty in Recent Years?" in Neill, Jon, ed., Poverty and inequality: The political economy of redistribution_(1997): 27-41. Kalamazoo, Mich.: W. E. Upjohn Institute for Employment Research.

Blank, Rebecca M. and Alan S. Blinder. 1986. "Macroeconomics, Income Distribution, and Poverty", in Fighting Poverty: What Works and What Doesn't, Sheldon H. Danziger and Daniel H. Weinberg, ed. Cambridge, MA: Harvard University Press.

Blank, Rebecca and David Card. 1993. "Poverty, Income Distribution, and Growth: Are They Still Connected?” Brookings Papers on Economic Activity v1993, n2: 285325.

Bound, John, and Harry J. Holzer. 2000. "Demand Shifts, Population Adjustments, and Labor Market Outcomes During the 1980s." Journal of Labor Economics v.18 (1, January), pp. 20-54.

Cain, Glen and Ross Finnie. 1990. "The Black-White Difference in Youth Employment: Evidence for Demand-Side Factors." Journal of Labor Economics v.8 (1, part 2), pp. S364-S395.

Fitzgerald, John M. 1995. "Local Labor Markets and Local Area Effects on Welfare Duration.” Journal of Policy Analysis and Management 14 (1), pp.43-67.

Freeman, Richard. 2001. “The Rising Tide...” Working Paper No. 8155, National Bureau of Economic Research, March 2001.

Freeman, Richard B. and William M. Rodgers III. 1999. "Area Economic Conditions and The Labor Market Outcomes of Young Men in the 1990s Expansion." NBER Working Paper 7073. April.

Greene, William H. 1997. Econometric Analysis. Upper Saddle River, New Jersey: Prentice Hall. 
Hines, James Jr, Hilary Hoynes, and Alan Krueger. 2001. "Another Look at Whether a Rising Tide Lifts All Boats.” Working Paper No. 8412, National Bureau of Economic Research, August 2001.

Hoynes, Hilary W. 2000. "Local Labor Markets and Welfare Spells: Do Demand Conditions Matter?" The Review of Economics and Statistics LXXXII (3):351368, August.

Hoynes, Hilary W. 1999. "The Employment, Earnings, and Income of Less-Skilled Workers over the Business Cycle.” Madison WI: Institute for Research on Poverty Discussion Paper No.1199-99.

Tokle, J.G. and Wallace E. Huffman. 1991."Local Economic Conditions and Wage Labor Decisions of Farm and Rural Nonfarm Couples." American Journal of Agricultural Economics 73 (3):652-70 August.

Tolbert Charles M. and Molly Sizer. 1996. "U.S. Commuting Zones and Labor Market Areas: a 1990 Update.” U.S. Department of Agriculture Economic Research Service Staff Paper No. 9614. September. 
Table 1

Categorization of Commuting Zones and Sample Size

\begin{tabular}{|c|c|c|c|}
\hline Category & Type of Commuting Zone & 1998 sample size & Percent of sample \\
\hline 1 & Non-metro, small towns & 108 & 1.3 \\
\hline 2 & Non-metro, small urban center & 431 & 5.3 \\
\hline 3 & Non-metro, large urban center & 327 & 4.0 \\
\hline 4 & Metro, small & 974 & 11.9 \\
\hline 5 & Metro, medium & 2315 & 28.2 \\
\hline \multirow[t]{2}{*}{6} & Metro, major & 4044 & 49.3 \\
\hline & TOTAL & 8199 & \\
\hline
\end{tabular}

Note: Commuting Zone designations from Tolbert Charles M. and Molly Sizer, 1996, "U.S. Commuting Zones and Labor Market Areas: a 1990 Update." U.S. Department of Agriculture Economic Research Service Staff Paper No. 9614. September. Categorization is based on the size of the largest population center in the commuting zone. 
Table 2

Variable Definitions and Descriptive Statistics

\begin{tabular}{|c|c|c|c|c|}
\hline & $\begin{array}{c}\text { Abbreviated } \\
\text { Name }\end{array}$ & Variable Description & Mean & Std. Dev. \\
\hline \multicolumn{5}{|l|}{1998 Outcomes } \\
\hline Hourly Wage & hrwg & $\begin{array}{l}\text { If employed in 1998, hourly wage for } \\
\text { the respondent's main job. }\end{array}$ & 15.3506 & 16.5954 \\
\hline Weekly Wage & wkwg & $\begin{array}{l}\text { If employed in } 1998 \text {, weekly wage for } \\
\text { the respondent's main job. }\end{array}$ & 621.4267 & 508.8708 \\
\hline Employed & empl & $\begin{array}{l}\text { Indicates that the worker is employed at } \\
\text { the time of the } 1998 \text { interview. }\end{array}$ & 0.7991 & 0.4007 \\
\hline Out of the Labor Force & olf & $\begin{array}{l}\text { Indicates that the worker is out of the } \\
\text { labor force at the time of the } 1998 \\
\text { interview. }\end{array}$ & 0.1505 & 0.3576 \\
\hline Unemployed & unmp & $\begin{array}{l}\text { Indicates that the worker is unemployed } \\
\text { at the time of the } 1998 \text { interview. }\end{array}$ & 0.0394 & 0.1946 \\
\hline \multicolumn{5}{|l|}{ Personal Characteristics } \\
\hline Age & age79 & Age of the respondent in 1998. & 36.8982 & 2.3056 \\
\hline Years of Education & hgcslf & $\begin{array}{l}\text { Highest grade completed by the } \\
\text { respondent as of } 1998 .\end{array}$ & 13.0464 & 2.4628 \\
\hline Hispanic & hispanic & $\begin{array}{l}\text { Indicates that the respondent is } \\
\text { Hispanic. }\end{array}$ & 0.1578 & 0.3646 \\
\hline Black & black & Indicates that the respondent is black. & 0.2502 & 0.4331 \\
\hline Female & female & Indicates that the respondent is female. & 0.4953 & 0.5000 \\
\hline Married & marrd & $\begin{array}{l}\text { Indicates that the respondent is married } \\
\text { at the time of the } 1998 \text { interview. }\end{array}$ & 0.5570 & 0.4968 \\
\hline Years of Education for Parent & hgcparnt & $\begin{array}{l}\text { Highest grade completed by the } \\
\text { respondent's head parent. }\end{array}$ & 10.8108 & 3.8788 \\
\hline Number of Children & children & $\begin{array}{l}\text { Number of children the respondent has } \\
\text { at the time of the } 1998 \text { interview. }\end{array}$ & 2.0284 & 1.5465 \\
\hline South & so & $\begin{array}{l}\text { Indicates that the respondent resides in } \\
\text { the South at the time of the } 1998 \\
\text { interview. }\end{array}$ & 0.4057 & 0.4910 \\
\hline Rural & newrural & $\begin{array}{l}\text { Indicates that the respondent resides in } \\
\text { a rural area at the time of the } 1998 \\
\text { interview. Rural is defined as one of } \\
\text { the following: Non-Metro Small Town, } \\
\text { Non-Metro Small Urban, or Non-Metro } \\
\text { Larger Urban. Urban then defined as } \\
\text { one of the following: Small Metro, } \\
\text { Medium Metro, or Major Metro. }\end{array}$ & 0.1056 & 0.3074 \\
\hline \multicolumn{5}{|l|}{ Experience and Tenure } \\
\hline Total Work Experience (hours) & tothr & $\begin{array}{l}\text { Hours of work experience the } \\
\text { respondent has accumulated as of the } \\
1998 \text { interview. }\end{array}$ & 23520.3900 & 14406.8700 \\
\hline Job Tenure (weeks) & tenure & $\begin{array}{l}\text { If employed in 1998, weeks of tenure } \\
\text { the respondent has with his/her main } \\
\text { employer. }\end{array}$ & 290.9466 & 275.5144 \\
\hline
\end{tabular}


Table 2, continued

\begin{tabular}{|c|c|c|c|c|}
\hline \multicolumn{5}{|c|}{ Job Characteristics } \\
\hline Union Status & union & $\begin{array}{l}\text { If employed in } 1998 \text {, union status for the } \\
\text { respondent's main job. }\end{array}$ & 0.0510 & 0.2200 \\
\hline \multirow[t]{5}{*}{ Industry Category } & & $\begin{array}{l}\text { If employed in } 1998 \text {, industry category for the } \\
\text { respondent's main job. }\end{array}$ & & \\
\hline & indbc1 & Non-Service & 0.3452 & 0.4755 \\
\hline & indbc2 & Professional Service & 0.3037 & 0.4599 \\
\hline & indbc3 & Retail Service & 0.1262 & 0.3322 \\
\hline & indbc4 & Commercial Service & 0.2248 & 0.4175 \\
\hline \multirow[t]{6}{*}{ Occupation Category } & & $\begin{array}{l}\text { If employed in } 1998 \text {, occupation category for } \\
\text { the respondent's main job. }\end{array}$ & & \\
\hline & occbc1 & Trade & 0.2386 & 0.4263 \\
\hline & occbc2 & Lower-Skilled Business & 0.1579 & 0.3647 \\
\hline & occbc3 & Higher-Skilled Business & 0.1956 & 0.3967 \\
\hline & occbc4 & Lower-Skilled Service & 0.2013 & 0.4010 \\
\hline & occbc5 & Professional Service & 0.2066 & 0.4049 \\
\hline \multicolumn{5}{|c|}{ Local Economic Conditions } \\
\hline Employment Growth & total & $\begin{array}{l}\text { Employment growth from } 1997 \text { to } 1998 \\
\text { associated with the county the respondent } \\
\text { resides in at the time of the } 1998 \text { interview. }\end{array}$ & 0.0252 & 0.0184 \\
\hline Unemployment Rate & lnurate & $\begin{array}{l}\text { Natural log of the March } 1998 \text { unemployment } \\
\text { rate associated with the county the respondent } \\
\text { resides in at the time of the } 1998 \text { interview. }\end{array}$ & 5.1548 & 0.0277 \\
\hline
\end{tabular}

Descriptive statistics are for 1998. 
Table 3

Summary of Results: Impact of Local Unemployment Rate on Wage and Employment Outcomes

\begin{tabular}{|c|c|c|c|c|}
\hline & \multicolumn{2}{|c|}{ High School or Less } & \multicolumn{2}{|c|}{ More Than High School } \\
\hline & $\begin{array}{c}\text { Ln(Unemployment } \\
\text { Rate) }\end{array}$ & $\begin{array}{c}\text { Rural Interaction } \\
\text { Term }\end{array}$ & $\begin{array}{c}\text { Ln(Unemployment } \\
\text { Rate) }\end{array}$ & $\begin{array}{c}\text { Rural Interaction } \\
\text { Term }\end{array}$ \\
\hline \multicolumn{5}{|c|}{ Table 3A: Cross-Section 1998} \\
\hline Ln(Hourly Wage) & $\begin{array}{l}-0.1130 * * \\
(0.0235)\end{array}$ & $\begin{array}{l}0.0846 \\
(0.0543)\end{array}$ & $\begin{array}{l}-0.0442 \\
(0.0237)\end{array}$ & $\begin{array}{l}0.0446 \\
(0.0951)\end{array}$ \\
\hline Ln(Weekly Wage) & $\begin{array}{l}-0.1182 * * \\
(0.0269)\end{array}$ & $\begin{array}{l}0.0196 \\
(0.0817)\end{array}$ & $\begin{array}{l}-0.0399 \\
(0.0312)\end{array}$ & $\begin{array}{l}-0.0655 \\
(0.1241)\end{array}$ \\
\hline Employment & $\begin{array}{l}-.0435 \\
(0.1111)\end{array}$ & $\begin{array}{l}-0.5318 \\
(0.3658)\end{array}$ & $\begin{array}{l}-0.0979 \\
(0.1398)\end{array}$ & $\begin{array}{l}0.5710 \\
(0.5726)\end{array}$ \\
\hline \multicolumn{5}{|c|}{ Table 3B: Panel Data 1993-1998 } \\
\hline Ln(Hourly Wage) & $\begin{array}{l}-0.0666 * * \\
(0.0205)\end{array}$ & $\begin{array}{l}0.0523 \\
(0.0609) \\
\end{array}$ & $\begin{array}{l}-0.0014 \\
(0.0181)\end{array}$ & $\begin{array}{l}-0.0919 \\
(0.0714) \\
\end{array}$ \\
\hline Ln(Weekly Wage) & $\begin{array}{l}-0.0461 * \\
(0.0230)\end{array}$ & $\begin{array}{l}0.0357 \\
(0.0683)\end{array}$ & $\begin{array}{l}0.0203 \\
(-0.0214) \\
\end{array}$ & $\begin{array}{l}-0.1004 \\
(0.0844) \\
\end{array}$ \\
\hline Employment & $\begin{array}{l}-0.0236^{*} \\
(0.0119)\end{array}$ & $\begin{array}{l}-0.0666 \\
(0.0394)\end{array}$ & $\begin{array}{l}0.0047 \\
(0.0110)\end{array}$ & $\begin{array}{l}-0.0144 \\
(0.0453)\end{array}$ \\
\hline
\end{tabular}

Table 4

Summary of Results: Impact of Local Employment Growth on Wage and Employment Outcomes

\begin{tabular}{|c|c|c|c|c|}
\hline & \multicolumn{2}{|c|}{ High School or Less } & \multicolumn{2}{|c|}{ More Than High School } \\
\hline & $\begin{array}{l}\text { Annual Job } \\
\text { Growth }\end{array}$ & $\begin{array}{c}\text { Rural Interaction } \\
\text { Term } \\
\end{array}$ & $\begin{array}{c}\text { Annual Job } \\
\text { Growth }\end{array}$ & $\begin{array}{c}\text { Rural Interaction } \\
\text { Term }\end{array}$ \\
\hline \multicolumn{5}{|c|}{ Table 4A: Cross-Section 1998} \\
\hline Ln(Hourly Wage) & $\begin{array}{l}2.8541 * * \\
(0.5480)\end{array}$ & $\begin{array}{l}-0.7258 \\
(1.5992)\end{array}$ & $\begin{array}{l}2.1005 * * \\
(0.6738)\end{array}$ & $\begin{array}{l}-3.1187 \\
(2.0221)\end{array}$ \\
\hline Ln(Weekly Wage) & $\begin{array}{l}3.0854 * * \\
(0.5952)\end{array}$ & $\begin{array}{l}.0482 \\
(1.9716)\end{array}$ & $\begin{array}{l}1.9949 * \\
(0.8338)\end{array}$ & $\begin{array}{l}-1.7194 \\
(2.5876)\end{array}$ \\
\hline Employment & $\begin{array}{l}-4.8521 \\
(2.5765)\end{array}$ & $\begin{array}{l}7.3376 \\
(6.3915)\end{array}$ & $\begin{array}{l}-4.1335 \\
(3.8682)\end{array}$ & $\begin{array}{l}-9.7994 \\
(11.1990)\end{array}$ \\
\hline \multicolumn{5}{|c|}{ Table 4B: Panel Data 1993-1998 } \\
\hline Ln(Hourly Wage) & $\begin{array}{l}-0.3302 \\
(0.2862)\end{array}$ & $\begin{array}{l}-0.5457 \\
(0.6482)\end{array}$ & $\begin{array}{l}0.1350 \\
(0.2927)\end{array}$ & $\begin{array}{l}-0.2254 \\
(0.7389)\end{array}$ \\
\hline Ln(Weekly Wage) & $\begin{array}{l}-0.2690 \\
(0.3203) \\
\end{array}$ & $\begin{array}{l}-1.0486 \\
(0.7254) \\
\end{array}$ & $\begin{array}{l}0.2468 \\
(0.3464) \\
\end{array}$ & $\begin{array}{l}0.8859 \\
(0.8747) \\
\end{array}$ \\
\hline Employment & $\begin{array}{l}0.3792 * \\
(0.1680) \\
\end{array}$ & $\begin{array}{l}0.0451 \\
(0.3774) \\
\end{array}$ & $\begin{array}{l}0.0666 \\
(0.1757) \\
\end{array}$ & $\begin{array}{l}-0.3471 \\
(0.4271) \\
\end{array}$ \\
\hline
\end{tabular}


Figure 1

\section{Annual Job Growth - By Type of Commuting Zone}

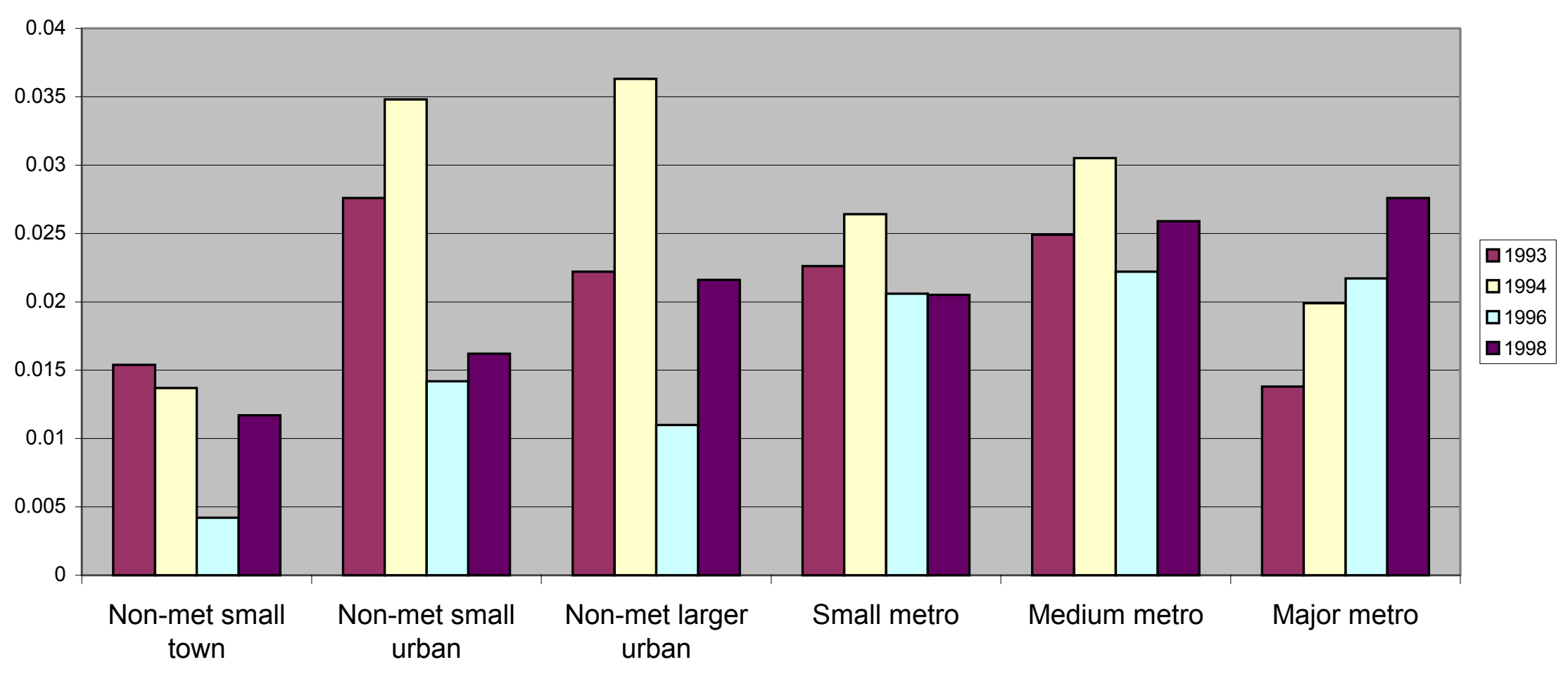


Figure 2

\section{Average Unemployment Rate By Type} of Commuting Zone

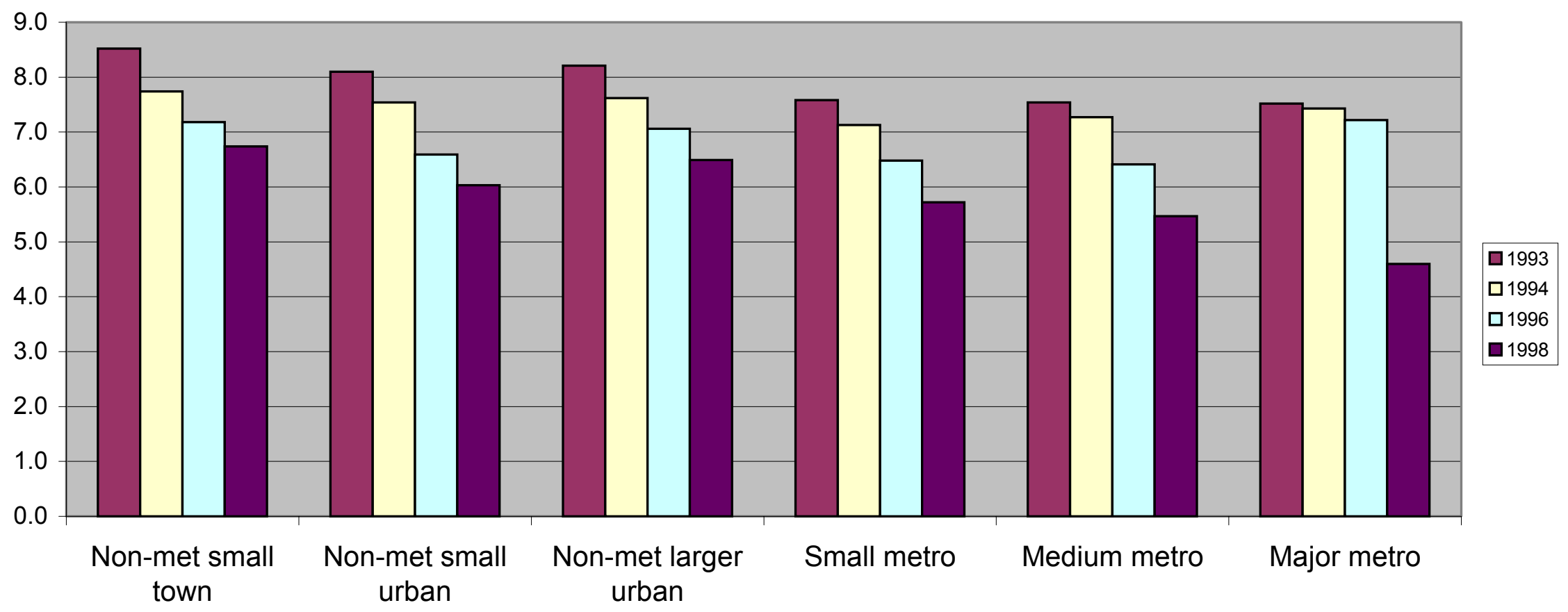


Table A.1: 1998 Hourly Wage Estimation With Local Unemployment Rate High School Education or Less

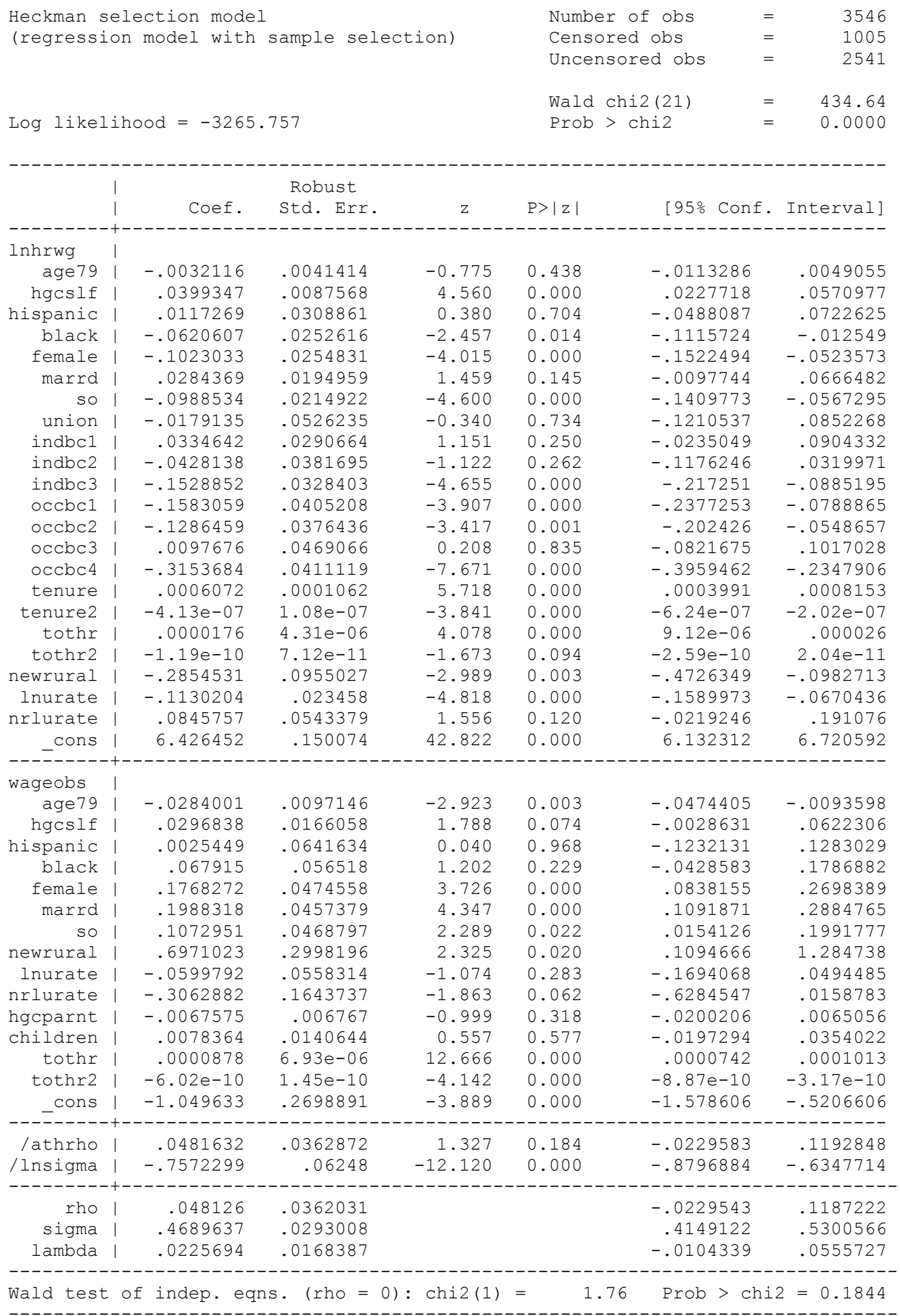


Table A.2: 1998 Weekly Wage Estimation With Local Unemployment Rate High School Education or Less

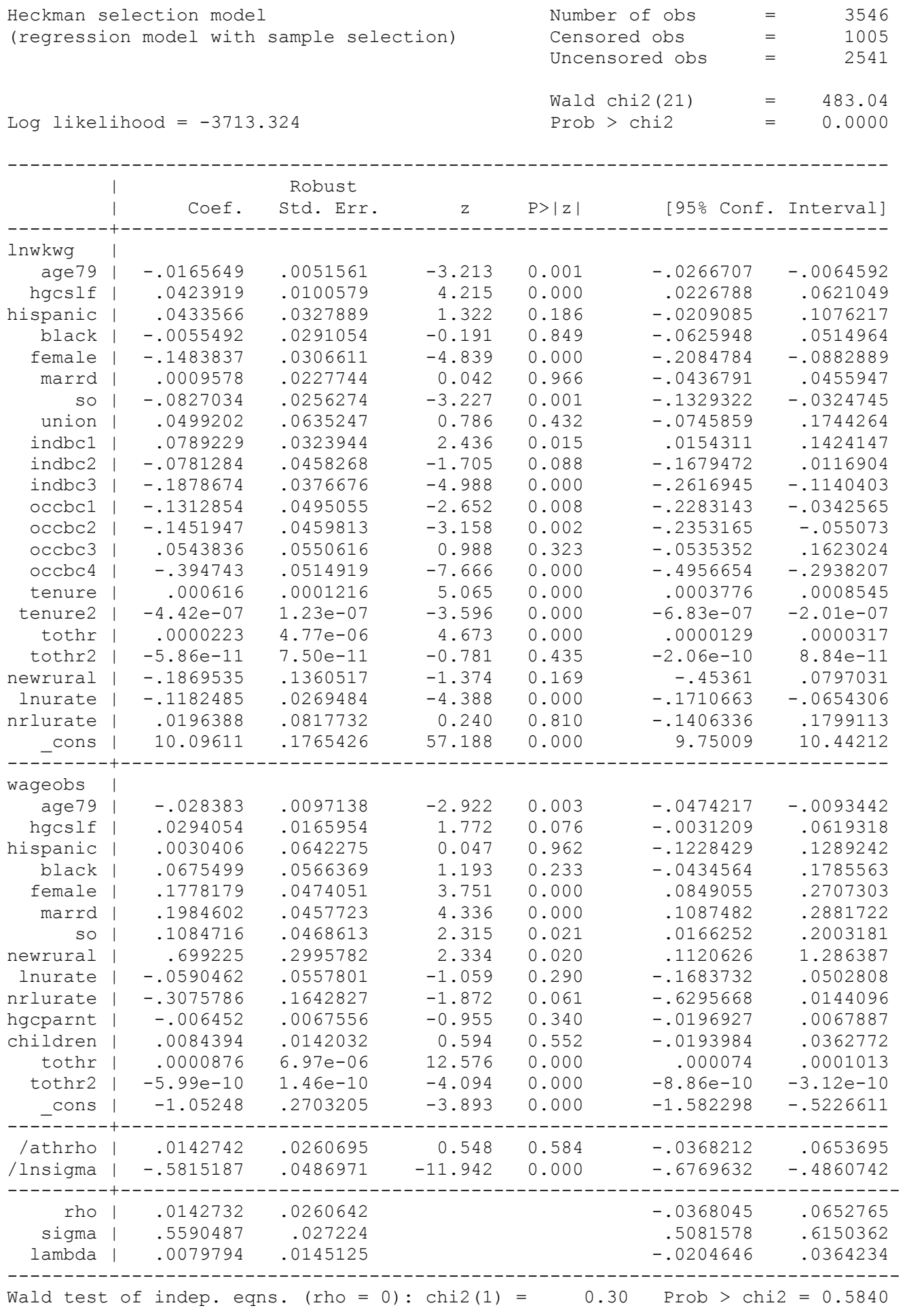


Table A.3: 1998 Employment Estimation With Local Unemployment Rate High School Education or Less

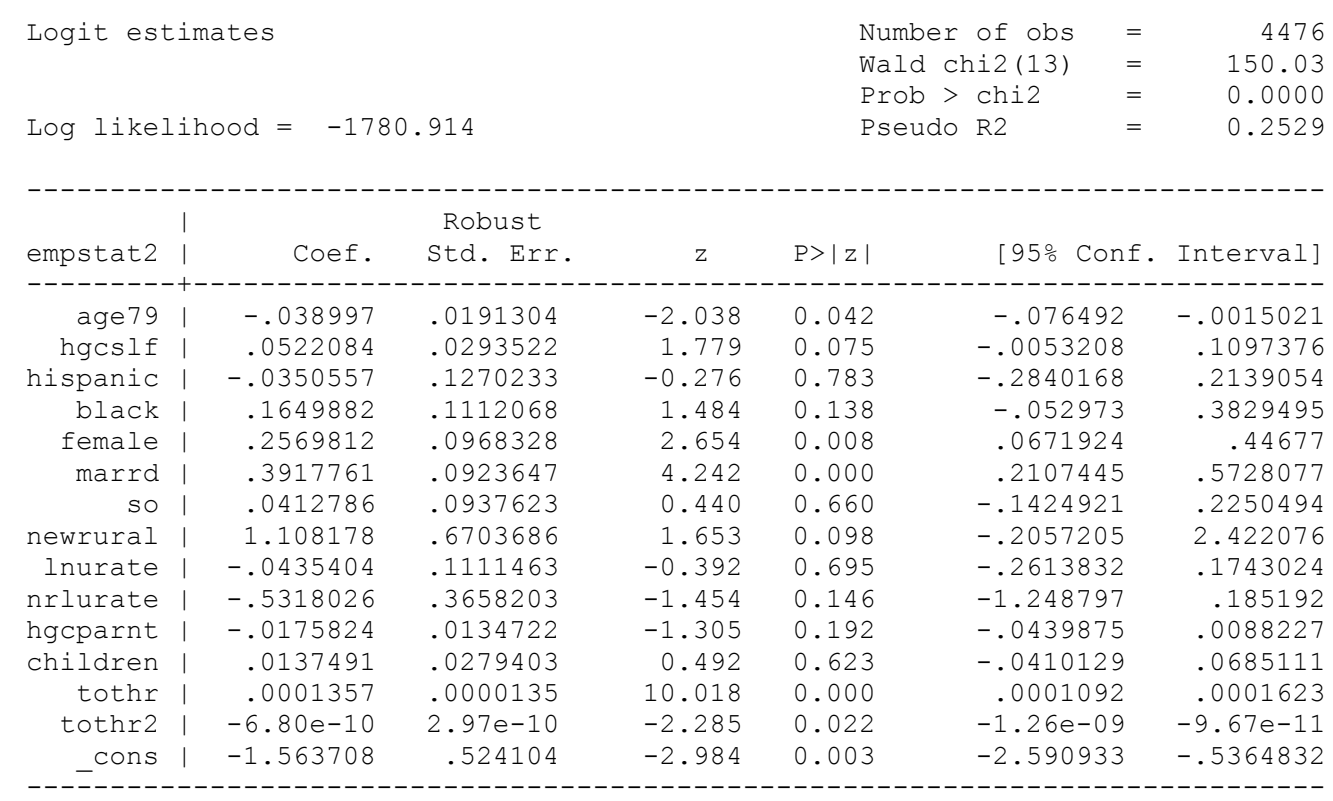


Table A.4: 1998 Hourly Wage Estimation With Local Unemployment Rate More Than High School Education

Heckman selection model

(regression model with sample selection)

$\begin{array}{llr}\text { Number of obs } & = & 2623 \\ \text { Censored obs } & = & 464 \\ \text { Uncensored obs } & = & 2159 \\ \text { Wald chi2(21) } & = & 1055.22 \\ \text { Prob }>\text { chi2 } & = & 0.0000\end{array}$

Log likelihood $=-2406.127$

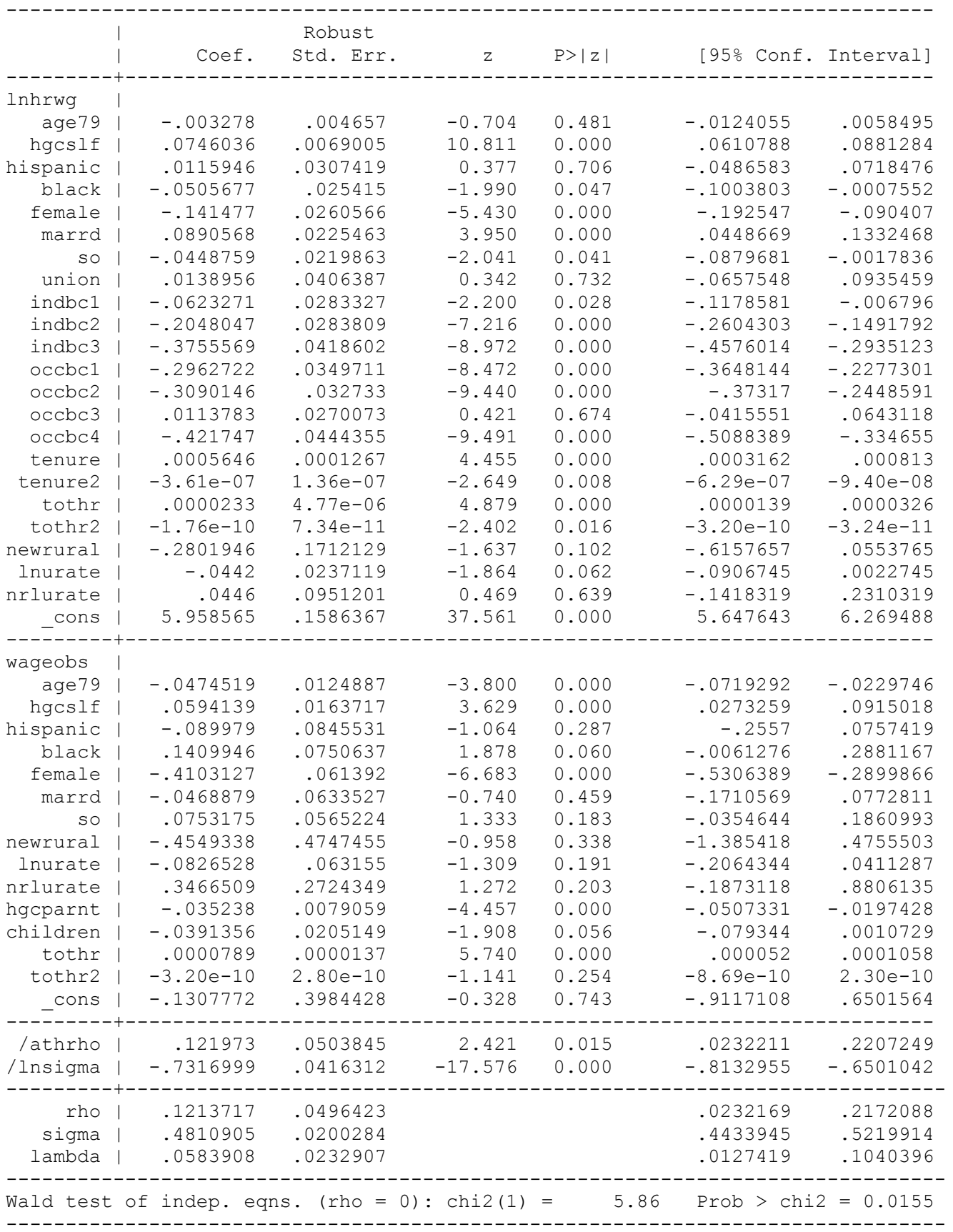


Table A.5: 1998 Weekly Wage Estimation With Local Unemployment Rate More Than High School Education

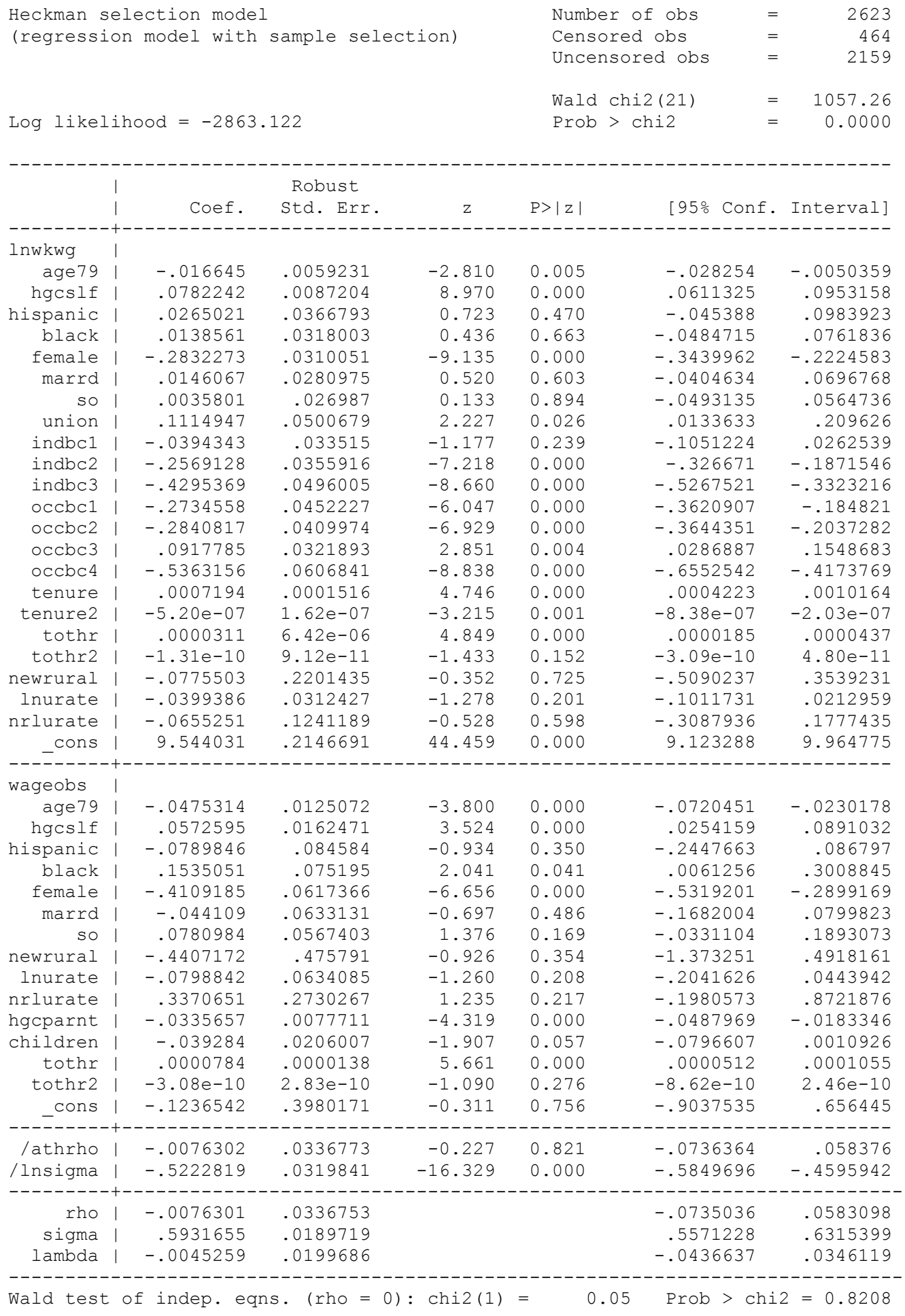


Table A.6: 1998 Employment Estimation With Local Unemployment Rate More Than High School Education

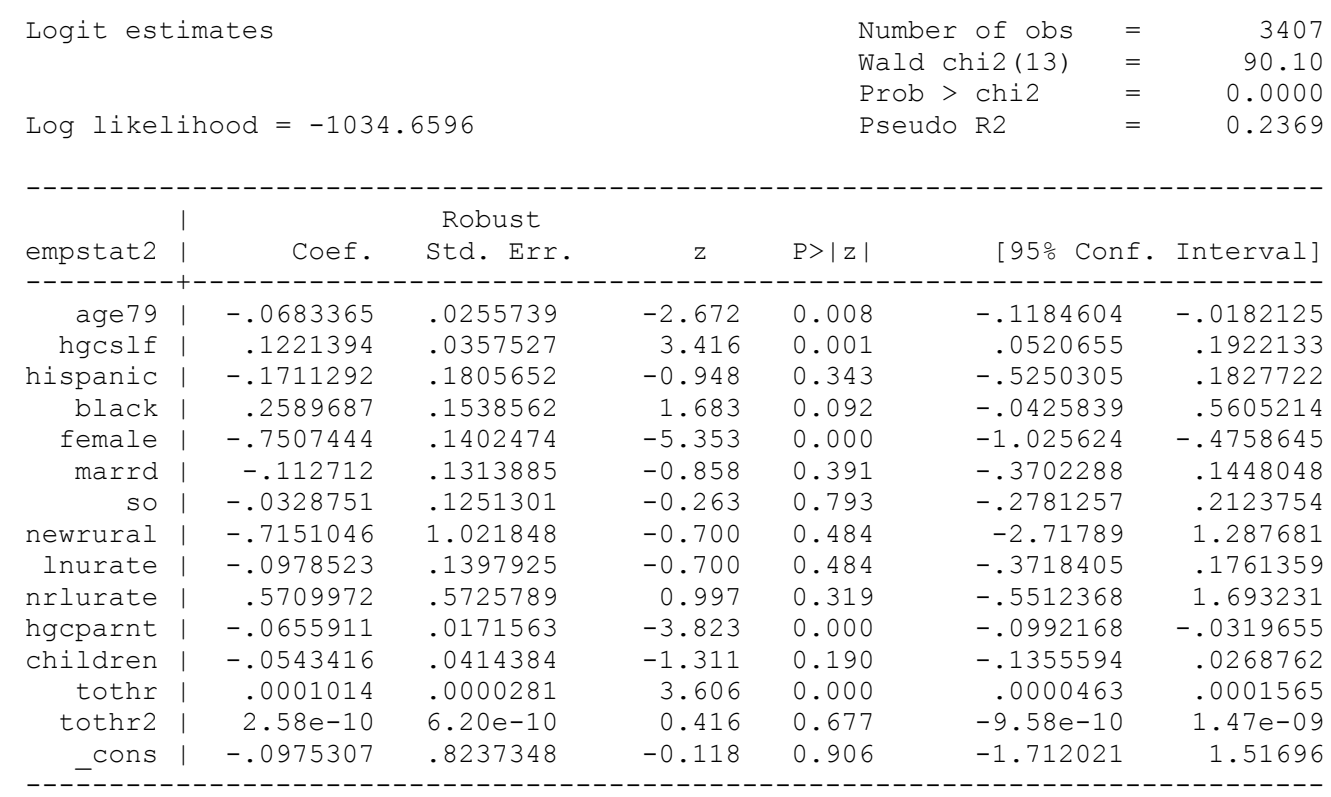

